\title{
Analysis of Hygienic Behavioral Intention on Students of Culinary
}

\author{
Sri Handajani \\ \{rihandajani@unesa.ac.id\}
}

Home Economic Department, Universitas Negeri Surabaya, Indonesia

\begin{abstract}
The purposes of this study were to analyze the hygienic behavioral intention on students of culinary using theory of planned behavior (TPB) and to analyze the prototype of hygienic behavioral intention on students of culinary during practical work. Respondents of this study were 150 culinary students, either in Diploma 3 or in Bachelor's degree (S1), at State University of Surabaya. The data of this study was collected by utilizing questionnaire method in order to know the attitude, subjective norm, Perceived Behavioral Control, and the intention to behave hygienic. The collected data was analyzed descriptively and multivariate method. The results of this study showed that intention to behave hygienic on the students was influenced by attitude and perceived behavioral control, which the attitude was influenced by consequence and evaluation, whether, $\mathrm{PBC}$ was influenced by power of individual feeling and ability to control his/her behavior. The subjective norm did not have any influence toward the enhancement of the intention to behave hygienic although motivation and normative belief had an influence toward the enhancement of subjective norm. Nevertheless, PBC had the strongest influence to the intention to behave hygienic.
\end{abstract}

Keywords: Enterprise Characters; Virtual Fashion Show; Pandemic Period

\section{Introduction}

Hygienic practice in system of food production is an effort that is done by food handlers to avoid spoiled food and to avoid reducing quality of the food. Hygienic practice is a part of food hygiene that aims for food surveillance and food prevention so that the food was not contaminated by bacteria either directly or indirectly. The students of culinary are food handlers, which everyone handles food and has important role in the moving and the prevention of disease from the food [1]. In learning process at campus, the culinary students related more with the food production, started from the ingredient preparation until the presentation. The bachelor and diploma 3 students of culinary in field of Home Economic Department, Faculty of Engineering, State University of Surabaya were claimed to be competent either in theory or in practice on the field of: food processing (continental, oriental, Indonesian), cake processing, technology of food processing, management of bakery and pastry, cake decoration, chocolate and sugar confectionery, and many others.

More than $50 \%$ of learning time at campus was used to practice food processing at laboratory of culinary. Regarding the competence and function from the food handler, it was important for the students to accustom themselves to practice hygienically. Hygienic practice in handling food had not been done well although the students had gotten the knowledge. This case was appropriate with the result of study [2]-[3]-[4]. In fact, the knowledge of the food 
handlers was not always applied into their behavior to process the food well or every change of their behavior in the work place only occurred for a while [5]. As the culinary students at State University of Surabaya also had gotten the knowledge of hygiene sanitation of food, however, they did not apply it in practice of food processing.

The theory of planned behavior [6] had proved success as the theoretical model with various professional applications. The existence of various studies that applied the theory of planned behavior as the basic theory showed that this theory was flexible to be applied for various fields of study. The purposes of this study to analyze the hygienic behavioral intention on culinary students in field of Home Economic Department, Faculty of Engineering, at State University of Surabaya and to arrange a control prototype of hygienic behavioral intention by improving the learning process regarding the handling of hygienic behavior on the culinary students

\section{Methodology}

This study was a policy study. Respondents of this study were Bachelor and Diploma 3 students of culinary department from various age class in field of Home Economic Department, Faculty of Engineering, State University of Surabaya, which was 242 students. The sampling of this study was collected in random sampling and the determination of the total of sampling utilized table that was developed by Krejcie and Morgan [7]. Therefore, the total of the sample was 150 respondents. The data collection involved primer data (attitude, subjective norm, Perceived Behavioral Control, and the intention to behave hygienic) and secondary data. Meanwhile, the method that was utilized to collect the data was questionnaire and documentation. Descriptive analysis was utilized in order to identify the respondents' character and to describe each variable of the study, which were attitude, subjective norm, Perceived Behavioral Control and the intention. Whether, multivariate analysis was utilized to analyze the influence of exogenous variable toward endogenous variable (the model of hygienic behavior). Moreover, the analysis technique that was utilized was Partial Least Square (SmartPLS software 2.0.M3 version).

\section{Result and Discussion}

Most of the students who studied in this department was female students $(91,3 \%)$. However, there were also male students here because based on the fact that some of food service business needed male chef rather than female one. Most of the respondents' previous education was Senior High School or Vocational High School (out of the department of culinary) (74\%), and from the Vocational High School in the department of culinary was only $26 \%$. The semester of the students (respondents) was in 2nd,4th,6th, and 8th semester. The students, who were at these semesters, showed the number of the subjects of practice that had been taken. The practice subjects of culinary department in Bachelor's degree overall were 18 subjects, meanwhile, in Diploma 3 were 20 subjects.

More numbers of semester had been taken, more knowledge and practice had been done, particularly for Diploma 3 students who were in Department of culinary, that had more practice rather than theory. In order to determine whether there was influence or not between the variables, it was important to test by using t-test in PLS shows in Table 1. Testing the 
relationship between variables showed one relationship insignificant that was the higher cannot improve hygienic behavior intention. The illustration of new structural model could be seen at the Figure 1.

In addition, it could be concluded that the intention to behave hygienic on the students was influenced by attitude and Perceived Behavioral Control, which attitude was influenced by consequence and evaluation, meanwhile, Perceived Behavioral Control was influenced by power of individual feeling and ability to control his/her behavior. Moreover, the subjective norm did not have any influence toward the enhancement of the intention to behave hygienic although motivation and normative belief influenced toward the enhancement of subjective norm. Between the attitude and Perceived Behavioral Control, Perceived Behavioral Control had the strongest influence toward the intention to behave hygienic.

Table 1. Testing the relationship between variable and acceptance hypothesis

\begin{tabular}{|c|c|c|c|c|c|}
\hline No. & $\begin{array}{c}\text { The relationship between } \\
\text { variables }\end{array}$ & $\begin{array}{l}\text { Estimate } \\
\text { Koefisien }\end{array}$ & $\begin{array}{l}\text { Standart Error } \\
\text { (STERR) }\end{array}$ & $\mathbf{t}$ & Hypothesis \\
\hline 1 & $\begin{array}{l}\text { The higher consequences, the } \\
\text { higher attitude }\end{array}$ & 0,939 & 0,017 & 55,705 & Significant \\
\hline 2 & $\begin{array}{l}\text { The higher evaluation, the } \\
\text { higher attitude }\end{array}$ & 0,697 & 0,056 & 12,467 & Significant \\
\hline 3 & $\begin{array}{l}\text { The higher motivation, the } \\
\text { higher subjective norm }\end{array}$ & 0,938 & 0,009 & 100,021 & Significant \\
\hline 4 & $\begin{array}{l}\text { The higher normative belief, } \\
\text { the higher subjective norm }\end{array}$ & 0,847 & 0,024 & 35,165 & Significant \\
\hline 5 & $\begin{array}{l}\text { The higher power of } \\
\text { individual feeling, the higher } \\
\text { perceived behavior control }\end{array}$ & 0,999 & 0,0002 & 4224,939 & Significant \\
\hline 6 & $\begin{array}{l}\text { The higher control behavior, } \\
\text { the higher perceived behavior } \\
\text { control }\end{array}$ & 0,998 & 0,0005 & 2126,624 & Significant \\
\hline 7 & $\begin{array}{l}\text { The higher attitude, the higher } \\
\text { intention }\end{array}$ & 0,251 & 0,113 & 2,212 & Significant \\
\hline 8 & $\begin{array}{l}\text { The higher subjective norm, } \\
\text { the higher intention }\end{array}$ & 0,104 & 0,086 & 1,212 & Not sign. \\
\hline 9 & $\begin{array}{l}\text { The higher perceived } \\
\text { behavior control, the higher } \\
\text { intention }\end{array}$ & 0,710 & 0,043 & 16,523 & Significant \\
\hline
\end{tabular}

In order to support the analysis of hygienic practical intention on culinary students, it was needed to have Focus Group Discussion (FGD) regarding the implementation of hygienic behavior on culinary students all the time when they practiced at campus laboratory. FGD was conducted by representation of culinary students from some age classes (ten students) from either Bachelor's degree or Diploma 3 of culinary department, 2 lecturers of the practical subject, 2 personnel of the culinary laboratory, and the author as a leader of discussion and recorder the result of discussion.

The result of FGD from the culinary students, the lecturers, and the personnel of the laboratory concluded that during this time, the hygienic behavior on the students in doing practice was not good enough. This was influenced by facilities and infrastructure, which supported the laboratory, particularly for sanitation facility, which was not complete enough. Besides, there was not Standard Operating Procedure (SOP) surely and it had not applied well, 
and the control in doing practice was not good enough from either the lecturers or the personnel laboratory, and many others.

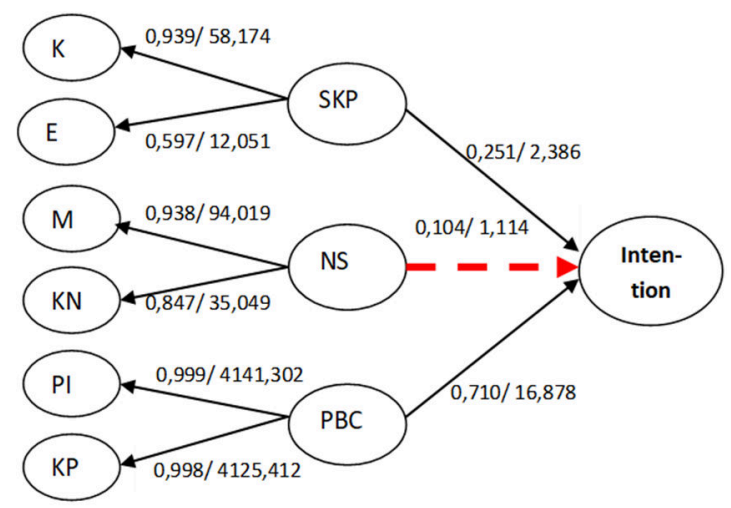

Fig 1. Final Structure Model

The highest consequence, the highest attitude to behave hygienic on the students. The coefficient estimates between consequence and attitude had positive and significant influence (the path of coefficient that had positive sign of 0.939 with t-statistic value of 55,705). The enhancement of consequence score would enhance the students' attitude. Furthermore, attitude was cognitive tendency, affective, and behavior, which were studied in order to respond either positively or negatively toward object, situation, institution, concept, or somebody. Consequence or belief strength was one of the attitudes toward behavior factor, which was positive or negative consequence that was felt by doing a behavior. The consequence of culinary students was positive attitude toward the statement that hygienic behavior was needed so that the practice could be done smoothly, they could work quietly, the food was produced clean and hygienic, the jobs became more practical and efficient.

However, the answer could have negative consequence if the students assumed by doing hygienic behavior, the practice time became longer so that it slowed the work ability that needed much additional costs. The existence of positive perception would support the existence of attitude toward hygienic behavior. Nevertheless, it would be on the contrary if it was negative perception, hence, positive attitude would not appear. The existence of those perception could not be separated from the background factors such as common attitude of someone toward something, personality traits, values, emotion, and the students' intelligence. Besides, it could not be separated from social factor and information factor. The social factors were age, gender, ethnicity, education, income, and religion. Meanwhile, the information factors were experience, knowledge, and media exposure.

\section{The decisive factor of attitude was evaluation (outcome evaluation).}

The evaluation was individual subjective value toward the attitude of consequence to behave. In other word, higher evaluation, higher attitude on the students to behave hygienic. The coefficient estimates between the evaluation and the attitude influenced positively and significantly. The evaluation influenced directly toward attitude which meant that every enhancement of evaluation score, it would enhance students' attitude. The subjective value on culinary students toward hygienic attitude was good. This was influenced by the background factors of hygienic behavior such as the personal, social, and the existence of information element that was obtained by the students. The practice to behave hygienic was a skill to do 
food processing and food service well based on the requirement of food hygiene and sanitation.

The attitude of consequence to behave hygienic on culinary students was showed by positive evaluation toward a necessity to behave hygienic in doing practice, hence, it could become good habits. The students believed that by doing hygienic practice, the dish that was produced was healthy. By doing practice in accordance with the SOP was a good necessity and it needed self-awareness to do and to accustom hygienic practice. Higher individual motivation (motivation to comply) influenced higher the subjective norm. The coefficient estimates between individual motivation and subjective norm influenced positively and significantly. Therefore, individual motivation influenced directly toward subjective norm, which meant that every enhancement score of individual motivation, it would enhance students' subjective norm.

The culinary students also felt that they had become their personnel rights in order to determine what they would do, and it was not determined by other people. Hence, when the support was perceived positively, the students would do that. In addition, it was appropriate with Peter and Olson's argument [8], subjective norm was formed by normative belief that related by doing what other people wanted them to do and motivation in order to comply other people's hope (motivation to comply). Higher normative belief influenced higher subjective belief to behave hygienic on culinary students. The coefficient estimates between normative belief and subjective norm influenced positively and significantly.

Therefore, the normative belief influenced directly toward subjective norm, which meant that every enhancement score of normative belief would enhance students' subjective norm. The existence of this positive correlation showed that normative belief on culinary students in order to comply with a desire or hope from the other people around them that was considered important was very great such as complying family's hope, lecturers', laboratory personnel's, friends', and a great desire from themselves to behave hygienic. Higher the power of individual feeling (direct or perceived power) influenced higher the perceived behavior control). The coefficient estimates between the power of individual feeling and perceived behavior control influenced positively and significantly.

Therefore, the power of individual feeling influenced directly toward perceived behavior control which meant that every enhancement score of the power of individual feeling would enhance students' perceived behavior control. The power of individual feeling (direct or perceived power) was individual ability to control the behavior toward the factors from the individual that pursued or supported the individual to perform behavior, which came from him or herself. The students' ability to control hygienic behavior was proved very well. This could be seen that among the other factors, the coefficient value of the power of individual feeling was higher than any others. This was the influence of the existence factors that caused the students such as experience and knowledge, which were gained during doing practice at campus.

Higher ability to control behavior (indirect or control belief) influenced higher perceived behavior control. The coefficient estimates between ability to control behavior with perceived behavior control influenced positively and significantly. Therefore, the ability to control behavior influenced directly toward PBC, which meant that every enhancement score of ability to control behavior would enhance the students' perceived behavior control. The coefficient value of ability to control behavior was rather similar if we compared with the ability to control behavior. The ability to control behavior (indirect or control belief) was individual ability to control the behavior toward outside factors that pursued or supported in order to show the behavior, which came from out of the him or herself. As well as the power 
of individual feeling (direct or perceived power) that the coefficient of ability to control behavior (indirect or control belief) on culinary students was greater. This was caused by the influence of laziness, emotion, work habits which were always in hurry, lack of awareness, and there were influences from friends.

Higher attitude influenced higher intention to practice hygienic. The coefficient estimates between the attitude and the intention influenced positively and significantly. Therefore, the attitude influenced directly toward the intention, which meant that every enhancement score of attitudes would enhance the students' intention. As one of the decisive intentions, the negative attitude or low attitude influenced the low intention. The attitude of culinary students showed positive attitude although the coefficient value was not high enough. Hence, the intention would be positive too.

However, higher subjective norm could not enhance the intention to practice hygienic. The coefficient estimates between subjective norm and intention influenced positively, but not significantly. Therefore, subjective norm did not influence directly toward the intention. Moreover, a belief was not always correct, hence, it would not be a guarantee toward the truth. Nonetheless, this belief would support the culinary students to consider seriously of what the people's hope or told was, which was assumed important to take an action. However, this had not been able to enhance the intention on culinary students to behave hygienic. Moreover, the students' intention was gained from subjective norm that they had, and the students' character such as previous education, age, motivation, social environment, and many others. The existence of insignificant correlation showed that the food handlers' subjective norm was higher, and it would not influence in increasing the students' intention to behave hygienic.

Higher perceived behavior control influenced higher intention to behave hygienic.

In this study, it was proved from the result of structural model test, which higher perceived behavior control influenced higher intention to behave hygienic. Oh and Hsu proved that the subset of perceived behavior control could influence the intention to behave [9]. For students in doing hygienic practice was under their control and in doing so was actually a good thing.

The model of the control of hygienic behavior on culinary students that was developed, as follow:

a. Perceived Behavior Control

Perceived behavior control gave the greatest contribution toward the implementation of the intention to behave hygienic directly. The activity that was planned in order to enhance the perceived behavior control was by doing activity: (1) providing and applying SOP; (2) Completing the facilities which were less such as work tools, sink, temporary trash bin and waste disposal, bathroom, locker, etc; (3) Giving sanction for anybody who violated the SOP; (4) Doing certain evaluation toward the work performance (hygienic behavior); (5) Doing the assessment or cross observation of hygienic practice among student groups.

b. Attitude

The interventions in order to enhance the attitude on culinary students in doing hygienic practice were : (1) inviting the practitioner in the field of culinary such as chef who could show the work procedure in work place; (2) Conducting an observation of hygiene sanitation to food industry that had applied the guarantee standard of food safety; (3) Providing and locating posters regarding to hygienic behavior in some places, which were easy to be seen by everybody, and (4) All of the parties (lecturers, laboratory personnel, and students) together did hygienic practice in accordance with the procedure. By having well knowledge, the attitude that was formed was also better. In addition, this activity could enhance a belief in 
students' selves that it would need to practice hygienic in their daily work. This attitude was believed to have influence directly toward the intention to behave.

\section{Conclusion}

The intention to behave hygienic on the students was influenced by attitude and perceived behavior control, which the attitude was influenced by consequence (belief strength) and evaluation (outcome evaluation), meanwhile, perceived behavior control was influenced by the power of individual feeling and ability to control behavior. The subjective norm did not influence toward the enhancement of intention to behave hygienic, although motivation and normative belief influenced toward the enhancement of subjective norm. Moreover, between attitude and perceived behavior control, perceived behavior control had the strongest influence toward the intention to behave hygienic. The model of the control of intention to behave hygienic on culinary students had well relevance and well prediction. If this model was applied, it could be predicted that it could enhance the intention and hygienic behavior on Kitchen and Pastry students.

The recommendations of this study were: Designing a right SOP for every kinds of laboratory and controlling the implementation.

\section{References}

[1] Ajzen I. 1991. The Theory of Planned Behavior. Organizational Behavior and Human Decision Processes. 50(2) 179-211.

[2] [2] Clayton R., Andersson P., Gale N.H, Gillis C., and Whitehouse M. "Practise Determination of The Istopic Composition of Sn Using MC-ICP-MS”. Journal Anal. At. Spectrom, 17:12481256,2002

[3] [3] Green L.R., and Selman C. "Factors Impacting Food Workers' and Managers' Safe Food Preparation Practices: A Qualitative Study". Food Protection Trends, 25(12), 981-990, 2005.

[4] [4] Powell S.C., Attwell R.W., and Massey S.J. "The Impact of Training on Knowledge and Standards of Food Hygiene A Pilot Study". International Journal of Environmental Health Research 7: 329-334, 1997

[5] [5] Powell S.C., Attwell R.W., and Massey S.J. "The Impact of Training on Knowledge and Standards of Food Hygiene A Pilot Study". International Journal of Environmental Health Research 7: 329-334, 1997

[6] [7] Seaman P., Eves A. "Efficacy of The Theory of Planned Behavior Model in Predicting Safe Food handling Practices". Food Control Journal 21:983-987, 2008.

[7] [8] Krejcie, Robert V. dan Daryle W. Morgan. 1970. "Ditermining Sample Size for Research Activities", Educational and Psychological Measurment. 30: 607-610

[8] [9] Peter J.P., and Olson J.P. 1999. Consumer Behavior. Perilaku Konsumen dan Strategi Pemasaran. Jilid I Edisi 4. Terjemahan Sihombing D. Jakarta: Erlangga.

[9] [10] Oh H., and Hsu C.H.C. "Volitional Degrees of Gambling Behaviors". Annuals of Tourism Research. 28(3): 618-637, 2001

[10] [11] Isara A.R., and Isah E.C. "Knowledge And Practice of Food Hygine and Safety Among Food Handlers in Fast Food Restaurants in Benin City", Edo State, Niger. Postgraduate Medical Journal, 16(3): 207-212, 2009.

[11] Okun M.A., and Sloane E.S. 2002. Application of Planned Behavior Theory to Predicting Volunteer Enrollment by College Students in A Campus-Based Program Social Behavior and Personality. Tempe: Arizona State University 